\title{
Porphyrobacter dokdonensis sp. nov., isolated from sea water
}

\author{
Jung-Hoon Yoon, So-Jung Kang, Mi-Hwa Lee, Hyun Woo Oh \\ and Tae-Kwang Oh \\ Korea Research Institute of Bioscience and Biotechnology (KRIBB), PO Box 115, Yusong, \\ Taejon, Korea
}

Correspondence

Jung-Hoon Yoon

jhyoon@kribb.re.kr

Tae-Kwang Oh

otk@kribb.re.kr

\begin{abstract}
A Gram-negative, non-motile, non-spore-forming, slightly halophilic bacterial strain, DSW-74 ${ }^{\top}$, was isolated from sea water off the island of Dokdo, Korea, and its taxonomic position was investigated by a polyphasic study. Strain DSW $-74^{\top}$ grew optimally at $37^{\circ} \mathrm{C}$ and in the presence of $2 \%$ $(\mathrm{w} / \mathrm{v}) \mathrm{NaCl}$. It contained $\mathrm{Q}-10$ as the predominant ubiquinone and $\mathrm{C}_{17: 1} \omega 6 \mathrm{c}$ and $\mathrm{C}_{18: 1} \omega 7 \mathrm{c}$ as the major fatty acids. Its DNA G $+\mathrm{C}$ content was $65.8 \mathrm{~mol} \%$. Phylogenetic analyses based on $16 \mathrm{~S}$ rRNA gene sequences revealed that strain DSW $-74^{\top}$ was most closely related to Porphyrobacter species. Similarity values between the $16 \mathrm{~S}$ rRNA gene sequence of strain DSW-74 ${ }^{\top}$ and those of the type strains of recognized Porphyrobacter species and of Erythromicrobium ramosum were in the range $97 \cdot 4-98 \cdot 7 \%$. Strain DSW $-74^{\top}$ exhibited $16 \mathrm{~S}$ rRNA gene sequence similarity values of $<97.5 \%$ to recognized Erythrobacter species and the other species used in the phylogenetic analysis. DNA-DNA relatedness levels and differential phenotypic properties made it possible to categorize strain DSW- $74^{\top}$ as representing a novel Porphyrobacter species. On the basis of the taxonomic data presented, it is proposed that DSW $-74^{\top}$ (=KCTC $12395^{\top}=\mathrm{DSM}$ $17193^{\top}$ ) should be classified in the genus Porphyrobacter as the type strain of a novel species, Porphyrobacter dokdonensis sp. nov.
\end{abstract}

The genus Porphyrobacter was proposed by Fuerst et al. (1993) and, at the time of writing, the genus comprises five recognized species: Porphyrobacter neustonensis (Fuerst et al., 1993), Porphyrobacter tepidarius (Hanada et al., 1997), Porphyrobacter sanguineus (Hiraishi et al., 2002), Porphyrobacter cryptus (Rainey et al., 2003) and Porphyrobacter donghaensis (Yoon et al., 2004). Phylogenetic analyses based on 16S rRNA gene sequences have shown that the genus Porphyrobacter belongs within the Alphaproteobacteria (Anzai et al., 2000; Hiraishi et al., 2002; Rainey et al., 2003; Yoon et al., 2004). Here we report on the detailed taxonomic characterization of a Porphyrobacter-like bacterial strain, designated DSW $-74^{\mathrm{T}}$.

Sea water collected from off the island of Dokdo, Korea, was used as the source for isolation of bacterial strains. Strain DSW $-74^{\mathrm{T}}$ was isolated by the standard dilution plating

Published online ahead of print on 31 December 2005 as DOI 10.1099/ijs.0.63840-0.

Abbreviation: BChl, bacteriochlorophyll.

The GenBank/EMBL/DDBJ accession number for the 16S rRNA gene sequence of strain DSW-74 ${ }^{\top}$ is DQ011529.

A figure showing the absorption spectra of sonicated cell extract and acetone-methanol cell extract of strain DSW- $74^{\top}$ is available as supplementary material in IJSEM Online. technique on marine agar 2216 (MA; Difco) at $30^{\circ} \mathrm{C}$. The type strains of the five recognized Porphyrobacter species were used as reference strains for DNA-DNA hybridization and phenotypic characterization: P. neustonensis DSM $9434^{\mathrm{T}}$, P. tepidarius DSM $10594^{\mathrm{T}}$, P. sanguineus DSM $11032^{\mathrm{T}}$ and $P$. cryptus DSM $12079^{\mathrm{T}}$ were obtained from the Deutsche Sammlung von Mikroorganismen und Zellkulturen (DSMZ), Braunschweig, Germany, and $P$. donghaensis SW $-132^{\mathrm{T}}$ was obtained from the study of Yoon et al. (2004). To investigate its morphological and some physiological characteristics, strain DSW $-74^{T}$ was routinely cultivated on MA at $30^{\circ} \mathrm{C}$. Cell morphology was examined by light microscopy (Nikon E600) and transmission electron microscopy. Transmission electron microscopy was also used to determine whether flagella were present in cells from exponentially growing cultures; cells were negatively stained with $1 \%(\mathrm{w} / \mathrm{v})$ phosphotungstic acid and the grids were examined after air-drying with a Philips CM-20 transmission electron microscope. The Gram reaction was determined by using the bioMérieux Gram stain kit according to the manufacturer's instructions. The $\mathrm{pH}$ range for growth was determined in marine broth 2216 (MB; Difco) that was adjusted to various $\mathrm{pH}$ values (initial $\mathrm{pH} 4 \cdot 5-10 \cdot 5$ at intervals of $0.5 \mathrm{pH}$ units). The $\mathrm{pH}$ was adjusted prior to sterilization to various levels by the addition of $\mathrm{HCl}$ or $\mathrm{Na}_{2} \mathrm{CO}_{3}$. Growth in the absence of $\mathrm{NaCl}$ was investigated in 
trypticase soy broth lacking $\mathrm{NaCl}$. Growth at various $\mathrm{NaCl}$ concentrations $[0.5 \%(\mathrm{w} / \mathrm{v})$ and $1.0-10.0 \%(\mathrm{w} / \mathrm{v})$ at intervals of $1.0 \%$ units] was investigated in $\mathrm{MB}$ and trypticase soy broth (Difco). Growth at various temperatures $\left(4-50{ }^{\circ} \mathrm{C}\right)$ was measured on MA. Growth under anaerobic conditions was determined after incubation in an anaerobic chamber on MA and on MA supplemented with nitrate, both of which had been prepared anaerobically using nitrogen. Catalase and oxidase activities and hydrolysis of casein and starch were determined as described by Cowan \& Steel (1965). Hydrolysis of Tweens 20, 40, 60 and 80 was determined as described by Cowan \& Steel (1965) with a modification that artificial sea water was used instead of distilled water. Hydrolysis of aesculin, gelatin and urea and reduction of nitrate were determined as described by Lanyi (1987) with a modification that artificial sea water was used instead of distilled water. The artificial sea water contained (per litre of distilled water) $23.6 \mathrm{~g} \mathrm{NaCl}, 0.64 \mathrm{~g} \mathrm{KCl}, 4.53 \mathrm{~g}$ $\mathrm{MgCl}_{2} \cdot 6 \mathrm{H}_{2} \mathrm{O}, 5.94 \mathrm{~g} \mathrm{MgSO}_{4} .7 \mathrm{H}_{2} \mathrm{O}$ and $1.3 \mathrm{~g} \mathrm{CaCl}_{2} \cdot 2 \mathrm{H}_{2} \mathrm{O}$ (Bruns et al., 2001). Hydrolysis of hypoxanthine, tyrosine and xanthine was investigated on MA with the substrate concentrations given by Cowan \& Steel (1965). Production of $\mathrm{H}_{2} \mathrm{~S}$ was tested as described by Bruns et al. (2001). Acid production from carbohydrates was determined using the method of Leifson (1963). Utilization of substrates as sole carbon and energy sources was tested as described by Baumann \& Baumann (1981) using supplementation with $2 \%$ (v/v) Hutner's mineral base (Cohen-Bazire et al., 1957) and $1 \%(\mathrm{v} / \mathrm{v})$ vitamin solution (Staley, 1968). For in vivo pigment-absorption spectrum analysis, two test strains were cultivated aerobically in the dark at $37^{\circ} \mathrm{C}$ in liquid Erythromicrobium/Roseococcus medium (Yurkov et al., 1994; DSMZ medium no. 767) with a modification that D-glucose was used instead of acetate. The cultures were washed twice by centrifugation using a MOPS buffer $(\mathrm{MOPS} / \mathrm{NaOH}$, $\left.0.01 \mathrm{M} ; \mathrm{KCl}, 0 \cdot 1 \mathrm{M} ; \mathrm{MgCl}_{2}, 0.001 \mathrm{M} ; \mathrm{pH} 7 \cdot 5\right)$ and disrupted by sonication with a Branson Sonifier 450. After removal of cell debris by centrifugation, the absorption spectrum of the supernatant was examined on a Beckman Coulter DU800 spectrophotometer. Susceptibility to antibiotics was tested on MA plates using antibiotic discs containing the following: $100 \mathrm{U}$ polymyxin $\mathrm{B}, 50 \mu \mathrm{g}$ streptomycin, $20 \mathrm{U}$ penicillin $\mathrm{G}, 100 \mu \mathrm{g}$ chloramphenicol, $10 \mu \mathrm{g}$ ampicillin, $30 \mu \mathrm{g}$ cephalothin, $30 \mu \mathrm{g}$ gentamicin, $5 \mu \mathrm{g}$ novobiocin, $30 \mu \mathrm{g}$ tetracycline, $30 \mu \mathrm{g}$ kanamycin, $15 \mu \mathrm{g}$ lincomycin, $15 \mu \mathrm{g}$ oleandomycin, $30 \mu \mathrm{g}$ neomycin or $100 \mu \mathrm{g}$ carbenicillin. Other physiological and biochemical tests were performed with the API 20E system (bioMérieux).

Cell biomass of strain DSW-74 ${ }^{\mathrm{T}}$ for DNA extraction and for isoprenoid quinone analysis was obtained by cultivation for 6 days in $\mathrm{MB}$ at $37^{\circ} \mathrm{C}$. Chromosomal DNA was isolated and purified according to the method described previously (Yoon et al., 1996), with the exception that RNase T1 was used in combination with RNase A to minimize contamination with RNA. The 16S rRNA gene was amplified by PCR using two universal primers (Yoon et al., 1998). Sequencing of the amplified 16S rRNA gene and phylogenetic analysis were performed as described by Yoon et al. (2003). Isoprenoid quinones were extracted according to the method of Komagata \& Suzuki (1987) and analysed using reversed-phase HPLC and a YMC ODS-A $(250 \times 4.6 \mathrm{~mm})$ column. For fatty acid methyl ester analysis, cell mass of strain DSW $-74^{\mathrm{T}}$ was harvested from agar plates after incubation for 7 days on MA at $37^{\circ} \mathrm{C}$. The fatty acid methyl esters were extracted and prepared according to the standard protocol of the MIDI/Hewlett Packard Microbial Identification System (Sasser, 1990). The DNA G + C content was determined by the method of Tamaoka \& Komagata (1984) with a modification that DNA was hydrolysed and the resultant nucleotides were analysed by reversed-phase HPLC. DNA-DNA hybridization was performed fluorometrically according to the method of Ezaki et al. (1989) by using photobiotin-labelled DNA probes and microdilution wells. Hybridization was performed with five replications for each sample. The highest and lowest values obtained in each sample were excluded, and the means of the remaining three values were quoted as DNA-DNA relatedness values.

Morphological, cultural, physiological and biochemical characteristics of strain DSW- $74^{\mathrm{T}}$ are given in the species description (see later) or are shown in Table 1, together with those of the five recognized Porphyrobacter species. Strain DSW $-74^{\mathrm{T}}$ produced bacteriochlorophyll (BChl) $a$ aerobically in the dark. The sonicated cell extract showed absorption maxima at approximately 457, 481, 583, 800, 835 and $862 \mathrm{~nm}$, which indicated the presence of carotenoids and BChl $a$ (see Supplementary Fig. S1 in IJSEM Online). The in vivo absorption spectrum of strain DSW- $74^{\mathrm{T}}$ was distinguishable from those of the other Porphyrobacter species, with the exception of $P$. sanguineus, in that three absorption maxima existed between 799 and $870 \mathrm{~nm}$ (Table 1). The acetone-methanol extract had in vitro absorption peak maxima at 454, 477 and $769 \mathrm{~nm}$, confirming the presence of carotenoids and BChl $a$ (Supplementary Fig. S1).

The almost complete 16S rRNA gene sequence of strain DSW $-74^{\mathrm{T}}$, comprising $1440 \mathrm{nt}$ (approximately $96 \%$ of the Escherichia coli 16S rRNA sequence), was determined in this study. The $16 \mathrm{~S}$ rRNA gene sequence analyses revealed that strain DSW- $74^{\mathrm{T}}$ was most closely affiliated to the genus Porphyrobacter. In the neighbour-joining tree based on $16 \mathrm{~S}$ rRNA gene sequences, strain DSW $-74^{\mathrm{T}}$ fell within the radiation of the cluster comprising Porphyrobacter species, and joined the type strain of P. cryptus at a bootstrap confidence level of $91 \cdot 1 \%$. Similar topologies were found in the tree generated with the maximum-parsimony algorithm (data not shown). The 16S rRNA gene sequence of strain DSW- $-74^{\mathrm{T}}$ exhibited similarity values of $97 \cdot 4-$ $98.7 \%$ to those of the type strains of the five recognized Porphyrobacter species and Erythromicrobium ramosum. Strain DSW-74 ${ }^{\mathrm{T}}$ exhibited $16 \mathrm{~S}$ rRNA gene sequence similarity levels of $93 \cdot 8-97 \cdot 5 \%$ to Erythrobacter species and of $<93.6 \%$ to all other species used in the phylogenetic analysis (Fig. 1). 
Table 1. Differential phenotypic characteristics of Porphyrobacter species

Species: 1, P. dokdonensis sp. nov.; 2, P. neustonensis, data from Fuerst et al. (1993) and this study; 3, P. tepidarius, data from Hanada et al. (1997) and this study; 4, P. sanguineus, data from Hiraishi et al. (2002) and this study; 5, P. cryptus, data from Rainey et al. (2003) and this study; 6, P. donghaensis, data from Yoon et al. (2004). n, Number of strains; +, positive reaction; -, negative reaction; W, weakly positive; V, variable reaction; data in parentheses are for the type strain. All species are aerobic, Gram-negative and non-sporulating. All species are positive for the presence of BChl $a$ and utilization of D-glucose. All species are negative for utilization of citrate.

\begin{tabular}{|c|c|c|c|c|c|c|}
\hline Characteristic & $1(n=1)$ & $2(n=4)$ & $3(n=1)$ & $4(n=2)$ & $5(n=2)$ & $6(n=2)$ \\
\hline Oxidase & + & - & $-{ }^{*}$ & + & + & + \\
\hline Motility & - & + & - & + & + & - \\
\hline Growth at $0 \%(\mathrm{w} / \mathrm{v}) \mathrm{NaCl}$ & $\mathrm{w}$ & + & + & - & $+^{*}$ & + \\
\hline Aesculin & + & $\mathrm{V}(+)$ & $+^{*}$ & $+^{*}$ & + & + \\
\hline Casein & - & $\mathrm{V}(-)$ & $-{ }^{*}$ & - & $-*$ & - \\
\hline Gelatin & - & - & - & - & + & - \\
\hline Starch & + & - & + & - & + & + \\
\hline Tween 80 & + & + & + & - & $+^{*}$ & + \\
\hline D-Mannose & - & + & $-{ }^{*}$ & - & - & - \\
\hline D-Trehalose & - & $\mathrm{V}(+)$ & $-*$ & $+^{*}$ & - & - \\
\hline D-Xylose & - & + & $-*$ & $-^{*}$ & + & $\mathrm{V}(+)$ \\
\hline L-Arabinose & - & - & $-{ }^{*}$ & - & - & - \\
\hline Sucrose & - & + & $-{ }^{\star}$ & + & + & $\mathrm{V}(-)$ \\
\hline Acetate & - & - & + & + & - & $\mathrm{V}(-)$ \\
\hline Succinate & + & $\mathrm{v}(+)$ & - & - & - & + \\
\hline L-Malate & + & - & - & - & - & + \\
\hline Pyruvate & + & $\mathrm{v}(+)$ & - & + & + & + \\
\hline L-Glutamate & - & $-{ }^{*}$ & + & + & + & - \\
\hline Maximum growth temperature $\left({ }^{\circ} \mathrm{C}\right)$ & 43 & 37 & 52 & 37 & $<60$ & $<50$ \\
\hline
\end{tabular}

${ }^{*}$ Data taken from this study for the type strain.

The predominant respiratory lipoquinone detected in strain DSW-74 ${ }^{\mathrm{T}}$ was ubiquinone-10 (Q-10) at a peak area ratio of approximately $82 \%$. Strain DSW- $74^{\mathrm{T}}$ had a cellular fatty acid profile that contained large amounts of unsaturated, straight-chain and hydroxy fatty acids; the major components ( $>1 \%$ of total fatty acids) were $\mathrm{C}_{17: 1} \omega 6 c(30 \cdot 6 \%$ ), $\mathrm{C}_{18: 1} \omega 7 c(28 \cdot 5 \%), \mathrm{C}_{16: 0}(8 \cdot 7 \%), \mathrm{C}_{15: 0} 2-\mathrm{OH}(6 \cdot 4 \%)$, $\mathrm{C}_{18: 0}(5 \cdot 0 \%), \mathrm{C}_{14: 0} 2-\mathrm{OH}(4 \cdot 5 \%), \mathrm{C}_{18: 1} \omega 5 c(3 \cdot 0 \%)$, $\mathrm{C}_{17: 1} \omega 8 c(2 \cdot 8 \%), \mathrm{C}_{17: 0}(2 \cdot 0 \%), \mathrm{C}_{13: 0} 2-\mathrm{OH}(1 \cdot 9 \%), \mathrm{C}_{16: 0}$ $2-\mathrm{OH}(1 \cdot 7 \%), \mathrm{C}_{15: 0}(1 \cdot 7 \%)$ and $\mathrm{C}_{16: 1} \omega 7 \mathrm{c}$ and/or iso- $\mathrm{C}_{15: 0}$ $2-\mathrm{OH}(1 \cdot 2 \%)$. Branched fatty acids were found as minor components in strain DSW-74 ${ }^{\mathrm{T}}$, which was also characteristic for the five recognized Porphyrobacter species (Hiraishi et al., 2002; Rainey et al., 2003; Yoon et al., 2004). This fatty acid profile was similar to those of Porphyrobacter species analysed previously, although there were differences in the proportions of some fatty acids, perhaps owing to differences in the cultivation conditions used, e.g. temperature and cultivation medium (Hiraishi et al., 2002; Rainey et al., 2003; Yoon et al., 2004). The DNA G + C content of strain DSW $-74^{\mathrm{T}}$ was $65 \cdot 8 \mathrm{~mol} \%$.

There were no distinct phenotypic, particularly chemotaxonomic, properties for differentiating strain DSW $-74^{\mathrm{T}}$ and the genus Porphyrobacter from the genera Erythrobacter and Erythromicrobium (Rainey et al., 2003). The relationship between the clade comprising strain DSW- $74^{\mathrm{T}}$ and the genera Porphyrobacter and Erythromicrobium and the clade 


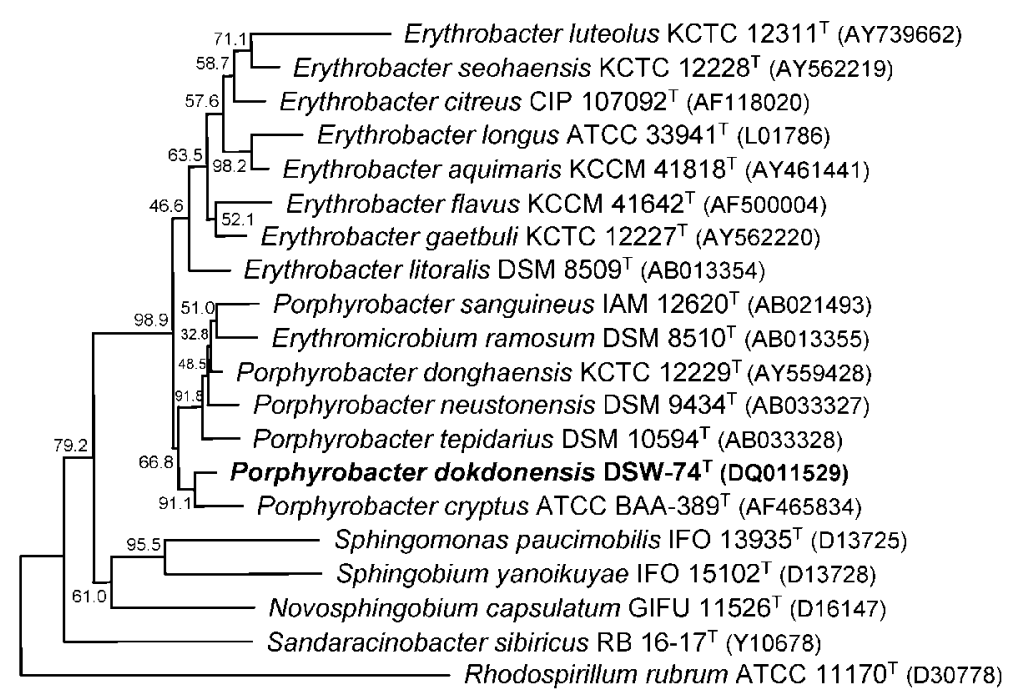

$\underline{0.01}$
Fig. 1. Neighbour-joining tree based on 16S rRNA gene sequences showing the phylogenetic positions of strain DSW-74 and representatives of some other related taxa. Rhodospirillum rubrum ATCC $11170^{\top}$ was used as an outgroup. Bar, 0.01 substitutions per nucleotide position. comprising Erythrobacter species was supported by a bootstrap resampling value of $98.9 \%$ (Fig. 1). The genera Porphyrobacter and Erythromicrobium could not be clearly distinguished because they are not well defined chemotaxonomically and are intermixed phylogenetically (Rainey et al., 2003). Indeed, Rainey et al. (2003) considered the possibility of combining the genera Erythrobacter, Porphyrobacter and Erythromicrobium into a single genus. However, it is currently necessary to place strain DSW $-74^{\mathrm{T}}$ into one of the three genera. Based on its highest 16S rRNA gene sequence similarity values to Porphyrobacter species, strain DSW- $74^{\mathrm{T}}$ should be placed within the genus Porphyrobacter before taxonomic criteria regarding the above three genera are proposed. There are several differential phenotypic properties between strain DSW $-74^{\mathrm{T}}$ and recognized Porphyrobacter species, including motility, the abilities to hydrolyse and to utilize some substrates, maximum and optimal temperatures for growth, and absorption spectrum pattern of in vivo cell extracts (Table 1). The genetic distinctiveness was sufficient to assign strain DSW $-74^{\mathrm{T}}$ to a novel species within the genus Porphyrobacter (Wayne et al., 1987). Levels of DNA-DNA relatedness between strain DSW- $74^{\mathrm{T}}$ and the type strains of the five recognized Porphyrobacter species were in the range $9-25 \%$. Therefore, on the basis of the data presented, strain DSW $-74^{\mathrm{T}}$ should be classified in the genus Porphyrobacter as the type strain of a novel species, for which the name Porphyrobacter dokdonensis sp. nov. is proposed.

\section{Description of Porphyrobacter dokdonensis sp. nov.}

Porphyrobacter dokdonensis (dok.do.nen'sis. N.L. masc. adj. dokdonensis of Dokdo, from where the strain was isolated).
Cells are pleomorphic: cocci, ovals and rods $(0 \cdot 4-0 \cdot 6 \times$ $0 \cdot 5-2 \cdot 5 \mu \mathrm{m})$ are present. Cells are Gram-negative, nonspore-forming and non-motile. Colonies on MA are circular, smooth, slightly convex, reddish orange in colour and $0.5-1.0 \mathrm{~mm}$ in diameter after incubation for 7 days at $37^{\circ} \mathrm{C}$. Optimal growth occurs at $35-37^{\circ} \mathrm{C}$; growth occurs at 10 and $43^{\circ} \mathrm{C}$, but not at 4 or $44^{\circ} \mathrm{C}$. Optimal $\mathrm{pH}$ for growth is $7 \cdot 0-8 \cdot 0$; growth occurs at $\mathrm{pH} 5 \cdot 5$, but not at $\mathrm{pH} 5 \cdot 0$. Optimal growth occurs in the presence of $2 \%(\mathrm{w} / \mathrm{v}) \mathrm{NaCl}$; growth occurs weakly in the absence of $\mathrm{NaCl}$ and in the presence of $7 \%(\mathrm{w} / \mathrm{v}) \mathrm{NaCl}$, but not in the presence of $>8 \%(\mathrm{w} / \mathrm{v}) \mathrm{NaCl}$. Growth does not occur under anaerobic conditions on MA or on MA supplemented with nitrate. Urease-negative. L-Tyrosine and Tweens 20, 40 and 60 are hydrolysed, but hypoxanthine and xanthine are not. $\mathrm{H}_{2} \mathrm{~S}$ and indole are not produced. Arginine dihydrolase, lysine decarboxylase, ornithine decarboxylase and tryptophan deaminase are absent. Maltose is utilized as the sole carbon and energy source, but benzoate, salicin and formate are not. Acid is not produced from the following substrates: L-arabinose, D-cellobiose, D-fructose, D-galactose, D-glucose, lactose, maltose, D-mannitol, D-mannose, D-melezitose, melibiose, D-raffinose, L-rhamnose, D-ribose, sucrose, D-trehalose, D-xylose, myo-inositol or D-sorbitol. Sensitive to penicillin G, chloramphenicol, cephalothin, novobiocin and carbenicillin, but not to polymyxin B, streptomycin, ampicillin, gentamicin, tetracycline, kanamycin, lincomycin, oleandomycin or neomycin. The predominant ubiquinone is Q-10. The major fatty acids are $\mathrm{C}_{17: 1} \omega 6 c$ $(30 \cdot 6 \%)$ and $\mathrm{C}_{18: 1} \omega 7 c(28 \cdot 5 \%)$. The DNA G $+\mathrm{C}$ content is $65.8 \mathrm{~mol} \%$ (HPLC). Other phenotypic properties are given in Table 1.

The type strain, DSW $-74^{\mathrm{T}} \quad\left(=\mathrm{KCTC} \quad 12395^{\mathrm{T}}=\mathrm{DSM}\right.$ $\left.17193^{\mathrm{T}}\right)$, was isolated from sea water. 


\section{Acknowledgements}

This work was supported by the 21C Frontier program of Microbial Genomics and Applications (grant MG05-0401-2-0) from the Ministry of Science and Technology (MOST) of the Republic of Korea. We are grateful to the Cultural Heritage Administration and the Gyeongsangbuk-do Administration of the Republic of Korea for aiding access to Dokdo.

\section{References}

Anzai, Y., Kim, H., Park, J.-Y., Wakabayashi, H. \& Oyaizu, H. (2000). Phylogenetic affiliation of the pseudomonads based on 16S rRNA sequence. Int J Syst Evol Microbiol 50, 1563-1589.

Baumann, P. \& Baumann, L. (1981). The marine Gram-negative eubacteria: genera Photobacterium, Beneckea, Alteromonas, Pseudomonas, and Alcaligenes. In The Prokaryotes, pp. 1302-1331. Edited by M. P. Starr, H. Stolp, H. G. Trüper, A. Balows \& H. G. Schlegel. Berlin: Springer.

Bruns, A., Rohde, M. \& Berthe-Corti, L. (2001). Muricauda ruestringensis gen. nov., sp. nov., a facultatively anaerobic, appendaged bacterium from German North Sea intertidal sediment. Int J Syst Evol Microbiol 51, 1997-2006.

Cohen-Bazire, G., Sistrom, W. R. \& Stanier, R. Y. (1957). Kinetic studies of pigment synthesis by nonsulfur purple bacteria. J Cell Comp Physiol 49, 25-68.

Cowan, S. T. \& Steel, K. J. (1965). Manual for the Identification of Medical Bacteria. London: Cambridge University Press.

Ezaki, T., Hashimoto, Y. \& Yabuuchi, E. (1989). Fluorometric deoxyribonucleic acid-deoxyribonucleic acid hybridization in microdilution wells as an alternative to membrane filter hybridization in which radioisotopes are used to determine genetic relatedness among bacterial strains. Int J Syst Bacteriol 39, 224-229.

Fuerst, J. A., Hawkins, J. A., Holmes, A., Sly, L. I., Moore, C. J. \& Stackebrandt, E. (1993). Porphyrobacter neustonensis gen. nov., sp. nov., an aerobic bacteriochlorophyll-synthesizing budding bacterium from fresh water. Int J Syst Bacteriol 43, 125-134.

Hanada, S., Kawase, Y., Hiraishi, A., Takaichi, S., Matsuura, K., Shimada, K. \& Nagashima, K. V. P. (1997). Porphyrobacter tepidarius sp. nov., a moderately thermophilic aerobic photosynthetic bacterium isolated from a hot spring. Int J Syst Bacteriol 47, $408-413$.
Hiraishi, A., Yonemitsu, Y., Matsushita, M., Shin, Y. K., Kuraishi, H. \& Kawahara, K. (2002). Characterization of Porphyrobacter sanguineus sp. nov., an aerobic bacteriochlorophyll-containing bacterium capable of degrading biphenyl and dibenzofuran. Arch Microbiol 178, $45-52$.

Komagata, K. \& Suzuki, K. (1987). Lipids and cell-wall analysis in bacterial systematics. Methods Microbiol 19, 161-203.

Lanyi, B. (1987). Classical and rapid identification methods for medically important bacteria. Methods Microbiol 19, 1-67.

Leifson, E. (1963). Determination of carbohydrate metabolism of marine bacteria. J Bacteriol 85, 1183-1184.

Rainey, F. A., Silva, J., Nobre, M. F., Silva, M. T. \& da Costa, M. S. (2003). Porphyrobacter cryptus sp. nov., a novel slightly thermophilic, aerobic, bacteriochlorophyll a-containing species. Int J Syst Evol Microbiol 53, 35-41.

Sasser, M. (1990). Identification of Bacteria by Gas Chromatography of Cellular Fatty Acids. Newark, DE: MIDI.

Staley, J. T. (1968). Prosthecomicrobium and Ancalomicrobium: new prosthecate freshwater bacteria. J Bacteriol 95, 1921-1942.

Tamaoka, J. \& Komagata, K. (1984). Determination of DNA base composition by reverse-phase high-performance liquid chromatography. FEMS Microbiol Lett 25, 125-128.

Wayne, L. G., Brenner, D. J., Colwell, R. R. \& 9 other authors (1987). Report of the ad hoc committee on reconciliation of approaches to bacterial systematics. Int J Syst Bacteriol 37, 463-464.

Yoon, J.-H., Kim, H., Kim, S.-B., Kim, H.-J., Kim, W. Y., Lee, S. T., Goodfellow, M. \& Park, Y.-H. (1996). Identification of Saccharomonospora strains by the use of genomic DNA fragments and rRNA gene probes. Int J Syst Bacteriol 46, 502-505.

Yoon, J.-H., Lee, S. T. \& Park, Y.-H. (1998). Inter- and intraspecific phylogenetic analysis of the genus Nocardioides and related taxa based on 16S rDNA sequences. Int J Syst Bacteriol 48, 187-194.

Yoon, J.-H., Kim, H., Kim, I.-G., Kang, K. H. \& Park, Y.-H. (2003). Erythrobacter flavus sp. nov., a slight halophile from the East Sea in Korea. Int J Syst Evol Microbiol 53, 1169-1174.

Yoon, J.-H., Lee, M.-H. \& Oh, T.-K. (2004). Porphyrobacter donghaensis sp. nov., isolated from sea water of the East Sea in Korea. Int J Syst Evol Microbiol 54, 2231-2235.

Yurkov, V., Stackebrandt, E., Holmes, A. \& 7 other authors (1994). Phylogenetic positions of novel aerobic, bacteriochlorophyll $a$ containing bacteria and description of Roseococcus thiosulfatophilus gen. nov., sp. nov., Erythromicrobium ramosum gen. nov., sp. nov., and Erythrobacter litoralis sp. nov. Int J Syst Bacteriol 44, 427-434. 